\title{
Biometrics, Race Making, and White Exceptionalism: The Controversy Over Universal Fingerprinting in Kenya ${ }^{1}$
}

\author{
Keren Weitzberg \\ University College London (Institute of Advanced Studies and History Department)
}

\begin{abstract}
This article excavates the imperial origins behind the recent turn towards digital biometrics in Kenya. It also tells the story of an important moment of race-making in the years after the Second World War. Though Kenya may be considered a frontier market for today's biometrics industry, fingerprinting was first introduced in the early twentieth century. By 1920, the Kenyan colonial government had dictated that African men who left their reserves be fingerprinted and issued an identity card (known colloquially as a kipande). In the late 1940s, after decades of African protest, the colonial government replaced the kipande with a universal system of registration via fingerprinting. This legislative move was accompanied by protests from members of the white settler community. Ironically, the effort to deracialize Kenya's identification regime only further normalized the use of biometrics, but also failed to fully undermine associations between white male exceptionalism and exemption from fingerprinting.
\end{abstract}

In recent years, there has been renewed interest by historians and scholars from a range of fields in the entanglements between capitalism and racial oppression. ${ }^{2}$ Historians of Africa have important contributions to make to this growing conversation on racial capitalism, an expression popularized and universalized by Cedric Robinson, but originally coined by intellectuals to refer

\footnotetext{
${ }^{1}$ This article was first workshopped at the Institute of Advanced Studies at University College London (UCL), where I received thoughtful and generative feedback from Prof. Tamar Garb, Prof. Megan Vaughan, Prof. Deborah Posel, Dr. Kafui Adjaye-Gbewonyo, Dr. Marissa Mika, Dr. Anna Marazuela Kim, and others. I am also grateful to Dr. Alden Young for reading an early draft of this article and to Prof. Keith Breckenridge for his insights into the history of biometrics in Kenya. Richard Ambani along with other staff at the Kenya National Archives were an invaluable resource as always. And thank you to the three anonymous $J A H$ reviewers who provided extremely useful commentary.

${ }^{2}$ See, for example, the collaborative syllabus and course, 'Slavery, Race, Capitalism', from the Robert L. Heilbrone Center for Capitalism Studies: http://www.publicseminar.org/2017/04/slavery-race-capitalism/.
} 
to South Africa's apartheid economy. ${ }^{3}$ Attending to the origins of this term invites us to re-center Africa within the history of racial capitalism and to see white settler states in Africa not as instances of racialist exceptionalism, but as manifestations of a global political economy. This article hones in on colonial Kenya as a case study able to provide insights into the racial character of capitalism. It does so through a focus on biometric identity cards, a technology that became globalized through British imperial expansion and which illuminates the interplay between racial subjectivities, market relations, and the bureaucratic infrastructures that sustain them.

Within European historiography, the identity card has largely been treated as a tool of state surveillance. ${ }^{4}$ Scholars of the colonial and postcolonial world, on the other hand, have tended to focus on the connections between registration and the construction of ethnic and racial hierarchies, seeing in identity document (ID) cards the antecedents of ethnocidal violence. ${ }^{5}$ Labor historians of Africa have been an exception to this trend, long recognizing the links between identity documents, fingerprinting, and the history of capitalist extraction. Historians of South Africa, in particular, have shown that the pass system helped mediate the contradictions of the migrant labor system, which sought to simultaneously enforce racial segregation and promote

\footnotetext{
${ }^{3}$ R. G. Kelly, 'What did Cedric Robinson mean by racial capitalism?' The Boston Review, 12 Jan. 2017, http://bostonreview.net/race/robin-d-g-kelley-what-did-cedric-robinson-mean-racial-capitalism. For recent work on the making of racial subjectivities in South Africa, see Deborah Posel's scholarship on consumerism and consumption; for example, D. Posel, 'Races to consume: revisiting South Africa's history of race, consumption and the struggle for freedom', Ethnic and Racial Studies, 33:2 (2010), 157-75.

${ }^{4}$ D. Lyon, Identifying Citizens: ID Cards as Surveillance (Cambridge, 2013); and E. A. Whitley, 'Perceptions of government technology, surveillance and privacy: the UK Identity Cards Scheme', in B. J. Goold and D. Neyland (eds.), New Directions in Surveillance and Privacy (New York, 2009), 154-77.

${ }^{5}$ Historians such as Nicholas B. Dirks and Mahmood Mamdani have shown that colonial authorities politicized and codified ethnic and caste differences through the use of censuses and identity cards. Dirks, Castes of Mind: Colonialism and the Making of Modern India (Princeton, 2011); and Mamdani, Define and Rule: Native as Political Identity (Johannesburg, 2013). For the links between eugenics and fingerprinting, see L. J. Davis, 'Constructing normalcy: the bell curve, the novel, and the invention of the disabled body in the nineteenth century', in L. J. Davis (ed.), The Disability Studies Reader (2n edn, New York, 2006), 3-16; and K. Breckenridge, Biometric State: The Global Politics of Identification and Surveillance in South Africa, 1850 to the Present (Cambridge, 2014).
} 
African labor mobility. ${ }^{6}$ Still, the insights from South African historiography cannot explain why the Kenyan registration system remained a bitterly fought over institution even as labor shortages eased and the colonial state began to accept the permanency of an African urban class. The case of Kenya brings into relief the layered entanglements between racialized labor systems and infrastructural technologies. Registration systems produced racial subjectivities through emotionally fraught, embodied practices that were linked to market mechanisms but often irreducible to the logics of capital.

Biometric ID cards were first introduced to Kenya in the early twentieth century under pressure from white settlers. Though often associated with today's digital landscape, biometry (the application of statistical analysis to biological data, such as fingerprints) originally developed in the crucible of empire as a nineteenth-century analog technology. ${ }^{7}$ By 1919 , the Kenyan colonial government had dictated that all African men above the age of 16 be fingerprinted and issued an identity card (known colloquially as a kipande, pl. vipande), which listed their ethnicity and employment history. Though the law technically applied to most adult men in the Colony, registration agents focused their efforts on laborers who left their reserves to seek work. ${ }^{8}$ Simultaneously a form of identification, a movement pass, and a work record, the kipande became one of the most hated emblems of African subjugation. Worn in a metal case around the neck, it was often likened to a dog collar or animal bell. ${ }^{9}$

\footnotetext{
${ }^{6}$ An earlier generation of historians of Kenya and South Africa examined the pass and ID system through a materialist lens. See, for example, G. N. Kitching, Class and Economic Change in Kenya: The Making of an African Petite Bourgeoisie 1905-1970 (New Haven, 1980); and M. Savage, 'The imposition of pass laws on the African population in South Africa 1916-1984', African Affairs, 85:339 (1986), 181-205.

${ }^{7}$ C. Sengoopta, Imprint of the Raj: How Fingerprinting Was Born in Colonial India (London, 2003).

${ }^{8}$ Originally enacted in 1915, the Registration of Natives Ordinance was only implemented after the end of the First World War. Though the law technically required all African men above the age of 16 to carry a kipande (aside from those living in the Norther Frontier District), colonial authorities did not register the population writ large.

${ }^{9}$ K. M'Inoti, 'The kipande: a colonial debate revisited', Economic Review, (Nairobi) 218 (1997), 19-20.
} 
In the late 1940s, after decades of African protest, the colonial government replaced the kipande with a universal system of registration via fingerprinting. ${ }^{10}$ This legislative move was accompanied by protests from members of the white settler community, who remonstrated vigorously to both metropolitan and colonial authorities against being subjected to a practice long reserved for African workers. ${ }^{11}$ Ironically, the effort to deracialize Kenya's identification regime after the Second World War not only further normalized the use of biometrics, but also failed to fully undermine associations between white male exceptionalism and exemption from fingerprinting. Race remained the not-so-silent referent around which post-war debates about universal fingerprinting revolved.

The patterns and material traces laid down by registration were not so easily effaced by legislative reform. This controversy speaks not only to an entrenched investment in whiteness, but also to the ways in which an assemblage of practices associated with registration gave form and meaning to the racial order. ${ }^{12}$ The kipande was more than simply an instrument of labor control. It prefigured and elicited certain forms of subjectivity, laying down embodied, archival practices that helped constitute and mediate the relationship between worker and employer, 'native' and settler. ${ }^{13}$

\footnotetext{
${ }^{10}$ Since its introduction in the early twentieth century, the kipande was a source of African grievance and the locus of political mobilization. In the early 1920s, both the Young Kavirondo Association and the East African Association protested against the registration certificate. H. Thuku, Harry Thuku: An Autobiography (Nairobi, 1970); and R. Maxon, 'The years of revolutionary advance, 1920-29', in W. R. Ochieng' (ed.), A Modern History of Kenya, 189-1980: In Honour of B. A. Ogot (London, 1989), 81.

${ }^{11}$ D. Brückenhaus, 'Identifying colonial subjects: fingerprinting in British Kenya, 1900-1960', Geschichte und Gesellschaft, 42:1 (2016), 6085.

${ }^{12}$ For studies of whiteness in Kenya, see D. K. Kennedy, Islands of White: Settler Society and Culture in Kenya and Southern Rhodesia, 1890-1939 (Durham, 1987); J. Lonsdale, 'Kenya: home county and African frontier', in Robert Bickers (ed.), Settlers and Expatriates: Britons Over the Seas (Oxford, 2014), 74-111; and J. McIntosh, Unsettled: Denial and Belonging among White Kenyans (Berkeley, 2016).

${ }^{13}$ For recent work on the documentary state that highlights paperwork as practice, see B. Messick, The Calligraphic State: Textual Domination and History in a Muslim Society (Berkeley, 1996); M. S. Hull, Government of Paper: The Materiality of Bureaucracy in Urban Pakistan (Berkeley, 2012); and B. Kafka, The Demon of Writing: Powers and Failures of Paperwork (New York, 2012). See also Madeleine Akrich's work on agency and technology. Akrich,
} 


\section{EMBODIED RACISM AND THE INFRASTRUCTURES OF REGISTRATION}

Across disciplinary fields, scholars have often focused on the sorting and classificatory implications of identity cards. ${ }^{14}$ Timothy Longman, for example, notes that ID cards helped to 'fix group identities' throughout colonial and postcolonial Africa'. ${ }^{15}$ Several studies have also cited the links between colonial-era identity cards and the forces that generated the Rwandan genocide. ${ }^{16}$ Yet while ID cards undoubtedly helped to codify ethnic and racial categories, registration and identification systems in Kenya and elsewhere were not always driven by a panoptic desire for surveillance or a classificatory longing for taxonomic order. ${ }^{17}$

Rather, the kipande scheme was first introduced at the behest of white settlers as a means of solving the problem of African resistance to wage labor. In the early twentieth century, white settler employers in East Africa faced persistent labor shortages and, looking aspirationally

\footnotetext{
'The description of technical objects', in W. E. Bijker and J. Law (eds.), Shaping Technology/Building Society, (Cambridge, MA, 1992), 205-58.

${ }^{14}$ S. Leigh Starr and G. C. Bowker, Sorting Things Out: Classification and its Consequence, (2n edn, Cambridge, MA, 1999); and S. Thompson, 'Separating the sheep from the goats: the United Kingdom's national registration programme and social sorting in the pre-electronic era', in C. J. Bennet and D. Lyon (eds.), Playing the Identity Card (London, 2008), 145-62.

${ }^{15}$ T. Longman, 'Identity cards, ethnic self-perception, and genocide in Rwanda', in J. Caplan and J. C. Torpey (eds.), Documenting Individual Identity: The Development of State Practices in the Modern World (Princeton, 2001), 346.

${ }^{16}$ M. Mamdani, 'Making sense of political violence in postcolonial Africa', in L. Geir and N. Olav (eds.), War and Peace in the 20th Century and Beyond (Singapore, 2003), 86, 90.

${ }^{17}$ As Timothy Longman notes, 'the meager available evidence regarding the origins of ... identity cards' in Rwanda suggests 'they were issued not with the intention of fixing ethnic membership but for more mundane administrative purposes'. Longman, 'Identity', 352. The extent to which colonial regimes were driven by a 'will to know' has been overstated in much of the early literature on colonial state surveillance. New work by Africanist scholars is reshaping scholarly understandings of state registration systems, calling into question the universality of Michel Foucault's paradigms of surveillance, James Scott's notions of legibility, and Max Weber's ideas of rationalization. See M. Foucault, The Birth of Biopolitics: Lectures at the College de France, 1978-1979, ed. M. Senellart, trans. G. Burchell (New York, 2008); J. C. Scott, Seeing Like a State: How Certain Schemes to Improve the Human Condition Have Failed (New Haven, 1998); and M. Weber, with intro. by C. Wright Mills, From Max Weber: Essays in Sociology, ed. H. H. Gerth (London, 1997). See also K. Breckenridge, 'No will to know: the rise and fall of African civil registration in twentieth-century South Africa', in K. Breckenridge and S. Szreter (eds.), Registration and Recognition: Documenting the Person in World History (Oxford, 2012), 115-137; and S. Pierce, 'Looking like a state: colonialism and the discourse of corruption in Northern Nigeria', Comparative Studies in Society and History, 48:4 (2006), 887-914.
} 
towards southern Africa, petitioned protectorate authorities for the creation of a pass system. ${ }^{18}$ As one white settler witness explained to the 1912-13 Labour Commission, with a pass system 'on the same lines as the South African one...it would be possible to get deserters back'. ${ }^{19}$ Though disinclined towards any legislation that might restrict the free movement of labor, the Commission considered 'a system of identification of natives' to be 'absolutely essential' due to the 'the absence of any means of identifying deserters' ${ }^{20}$ In 1915 , the protectorate government introduced the Native Registration Ordinance, though it was held in abeyance until after the First World War. ${ }^{21}$ Once introduced, the Ordinance proved a significant deterrent against desertions. ${ }^{22}$ A technology of governance taken for granted in much of Kenyan historiography, the kipande quickly became a fixture within the Colony's labor structure. Yet the links between the registration and the migrant labor systems are not well understood. ${ }^{23}$ Much emphasis has been placed on the ID card itself but not on the vast infrastructure supporting it. This ranged from chiefs, who validated Africans' identities and ethnic particulars, to registration agents, who captured fingerprints and submitted paperwork, to fingerprint experts, who categorized and filed millions of Kenyans' biometric and biographical data.

This human infrastructure supported a paper infrastructure that linked the body to what Allan Sekula refers to as 'the central artifact' of nineteenth-century realism: 'the filing cabinet' ${ }^{24}$

\footnotetext{
${ }^{18}$ See, for example, the 'Report of Land Committee, Presented to His Majesty's Commissioner, East Africa Protectorate', in C. Anderson and A. Cohen (eds.), The Government and Administration of Africa, 1880-1939, Volume IV (London, 2013 [orig. published 1905]), 24-25, 33, 37-39.

${ }^{19}$ East Africa Protectorate, Native Labour Commission, 1912-13: Evidence and Report (Government Printer, South Africa, 1913), 17.

${ }^{20}$ Ibid. 330.

${ }^{21}$ Official Gazette of the East Africa Protectorate, Vol XXII, no. 690, 14 Jan. 1920, 17.

${ }^{22}$ R. W. McGregor, Kenya from Within: A Short Political History (London, 1927), 190.

${ }^{23}$ B. Berman and J. Lonsdale, for instance, have overstated the scope and efficacy of the registration system. See 'Crises of accumulation, coercion and the colonial state: the development of the labor control system in Kenya, 1919-1929', Canadian Journal of African Studies/La Revue Canadienne des Études Africaines, 14:1 (1980), 55-81. ${ }^{24}$ A. Sekula, 'The body and the archive', October, 39 (1986), 16.
} 
The kipande listed the holder's personal details, including name, ethnicity ('tribe'), Native Reserve, and thumbprint. Such biodata existed in duplicate in the Central Finger Print Bureau in Nairobi, which also held the ten-print ink records of all kipande holders. Using methods developed in colonial India and South Africa, Kenyan officials categorized Africans' fingerprints using indexable codes, which allowed for a vast, searchable biometric database that could be cross-referenced against criminal records. ${ }^{25}$

Though often performative (the registration system always exhausted administrative capacity), this method enabled settlers and colonial officials to locate and verify the identity of any African subject issued with a kipande. Such a feat of mimesis was performed for the subcommittee tasked with re-evaluating the registration system in 1946, as pressure from African leaders mounted. At their very first meeting, the Committee toured the registration section of the Labour Department and were regaled with a demonstration of biometrics: 'An unknown African was interviewed outside the building and requested to give a set of his finger prints ... A set of finger prints were taken and within a short period the African was identified'. ${ }^{26}$ The 'rapidity and accuracy' of this presentation impressed the Committee and reinforced a hardening administrative belief that fingerprints were the apex of identification, one that affixed the African body to the archive. ${ }^{27}$ The efficacy of this analog system foreshadowed the electronic hyper speed of today's computerized databases.

This curated performance nevertheless veiled the day-to-day messiness of the registration system. The kipande was a living document — one that could be torn up, forged, overlooked,

\footnotetext{
${ }^{25}$ For more on the history and development of anthropometry and biometrics, see S. A. Cole, Suspect Identities: A History of Fingerprinting and Criminal Identification (Cambridge, MA, 2009). For insight into the searchability of the Central Finger Print Bureau, see Kenya National Archives (KNA) AG/35/25.

${ }^{26} \mathrm{KNA} \mathrm{AG} / 35 / 35$, 'Minutes of the first meeting of the sub-committee, labour advisory board held at the Labour Department on Sunday, 7 July 1946, At 9.30 AM', 3.

${ }^{27}$ Ibid.
} 
carried by a friend or relative, used to solicit bribes, or retooled by employee and employer. Among the seemingly immutable bodily personal details, it also bore marks of superiors and a record of one's interaction with the wage labor system. Endorsed by employers upon discharge, the kipande was filled with information regarding an African's employment history, including their wages and rations. These sections were particularly vulnerable to manipulation by employers willing to stretch the provisions of the law. ${ }^{28}$ The practice of withholding signatures, for example, enabled employers to keep African laborers in their service indefinitely. Though this practice that may have been welcomed by some African laborers who sought exemption from forced communal labor on the reserves, it also prevented workers (who were effectively kept on reserve) from being released to find other employment. ${ }^{29}$ The 'evil of granting indefinite leave' was one of the many ways that the registration system, rather than facilitating the mobility of labor, constricted labor supply by accommodating the needs of white settler capital. ${ }^{30}$

The kipande brought Africans into asymmetric negotiation not only with white settlers, but also with African civil servants. ${ }^{31}$ Every year, between 3,000 and 5,000 Africans were prosecuted for offences ranging from 'failure to carry the kipande, mutilation and alteration,' to 'the carrying of someone else's kipande', which entailed hefty fines or several months' imprisonment. ${ }^{32}$ Africans could be arrested if they could not produce their certificate while moving outside the reserves, a policy that greatly restricted their freedom of movement in urban

\footnotetext{
${ }^{28}$ KNA AG 35/17, letter from Acting Solicitor-General, P. A. McElwaine, to Colonial Secretary, 'Abuses of the provisions of the Native Registration Ordinance by employers', 20 Nov. 1925; and and TNA CO 533/413/6, 'Native Registration Ordinance, Kenya: extract from record of interview of Kenya native witnesses with Lord Passfield', 4 May 1931.

${ }^{29} \mathrm{KNA}$ AG/35/28, letter from Chief Native Commissioner to the Attorney General of Kenya, 8 June 1925.

${ }^{30}$ The National Archives, London, United Kingdom (TNA) CO/533/483/15, 'Comparative table: the Native Registration (Amendment) Bill, 1937', 1.

${ }^{31}$ For more on the surveillance of the black body, see S. Browne, Dark Matters: On the Surveillance of Blackness (Durham, 2015).

32 A. Clayton and D. C. Savage, Government and Labour in Kenya, 1895-1963 (London, 1974), 171. See also TNA CO 533/413/6, C. S. Eastwood, 'Memorandum', 20 June 1931.
} 
areas. ${ }^{33}$ Such policing practices were mediated not through a Weberian prism of bureaucratic efficiency but through the indiscriminate and often highly discretionary methods of low-ranking African police officers. In his memoir, Waruhiu Itote (General China) described how the Nairobi police, upon doing a sweep, would line up those detained by calling wafupi (short people) to the back and warefu (tall people) to the front. "Only they would pronounce it "warevu" which means clever people, that is those who had money for a bribe'. ${ }^{34}$ Inaudible and invisible to many colonial officials, such on-the-ground practices speak to the way that money, under many circumstances, became a de facto pass. ${ }^{35}$

Although African workers found various ways of evading arrest, deserting unpopular employers, striking deals with more favorable ones, discarding vipande, and adopting new personas, they always stood in danger of detection through the filing cabinet. Frequently treated as a more reliable witness than its possessor, the kipande was predicated on the silencing of African voices and the granting of literary and narrative power to state official and employers. In 1938, after checking a man's fingerprints, the Registrar of Natives confirmed that a worker on Brooke Farm in central Kenya was ‘in wrongful possession’ of another person's registration certificate and assured the employer that 'steps will be taken to arrange for his arrest' ${ }^{36}$ Reserved almost exclusively for the African worker, fingerprinting was a mute technology that inscribed and archived bodily markers and circumvented the political economy of literacy, enabling

\footnotetext{
${ }^{33}$ TNA CO 533/413/6, 'Evidence of native witnesses'. 'These [kipande] regulations make Kenya Africans strangers in their own land', wrote Jomo Kenyatta in 1932; see TNA CO 533/422/1, Kenyatta, General Secretary of the Kikuyu Central Committee, 'Memorandum of the Kikuyu Central Association to the Secretary of State for the Colonies', Feb. 1932.

${ }^{34}$ W. Itote, 'Mau Mau' General (Nairobi, 1967), 35.

${ }^{35}$ For the use of money as a de facto ID in contemporary Kenya, see S. Balakian, "Money is your government": refugees, mobility, and unstable documents in Kenya's Operation Usalama Watch', African Studies Review, 59:2 (2016), 87111. On the discretionary power of registration agents, see F. D. Markó, "WWe are not a failed state, we make the best passports:" South Sudan and biometric modernity', African Studies Review, 59:2 (2016), 113132. ${ }^{36} \mathrm{KNA}$ ABK/14/36, letter from Arthur T. Wise, Chief Registrar of Natives, to David Gillett of Brooke Farm, 11 Oct. 1938.
} 
subjects to be tracked and identified regardless of their own voiced explanations or written narratives. $^{37}$

While the fingerprint was a code intelligible only to those trained in biometric techniques, writing too could exceed its semantic meaning, sign and signifier splitting off in new directions, marks on paper becoming cypher. In 1925, the colonial government was forced to amend the Native Registration Ordinance to prevent employers from signing off vipande in red ink. As the Chief Registrar of Natives discovered, the use of red ink was intended to 'warn potential employers that the holder of a certificate bearing such an endorsement was unsatisfactory' and was widely 'used by the Nairobi housewives'. ${ }^{38}$ Not unlike the semantic slippage of African police officers, white settlers had developed their own coded mode of communication to voice their complaints covertly, circumventing the modest constraints imposed on them by colonial authorities. ${ }^{39}$ There was no such recourse for dissatisfied African workers. As former colonial officer Ross W. McGregor noted in his pointed indictment of British rule in Kenya, the registration 'system was designed to operate to the advantage of the worst employers'. ${ }^{40}$

Such power dynamics were nevertheless turned on their head by an anonymous settler, who justified the use of red ink in a letter to the Daily Observer's editor in November 1925: 'What other remedy has an employer? We are completely at their mercy. Some method must be devised whereby a boy's [sic] record may be known, otherwise I am afraid there will be serious trouble'. ${ }^{41}$ Defensive settler responses were colored by anxieties about African men, particularly

\footnotetext{
${ }^{37}$ Breckenridge, Biometric State, 11, 136, 216.

${ }^{38}$ KNA AG/35/17, letter from the Chief Registrar of Natives to the Chief Native Commissioner, 6 Oct. 1925.

${ }^{39}$ Nor were colonial officials able to fully curb such practices. In 1937, the government introduced yet another amendment to the Native Registration Ordinance to standardize the color of ink. TNA CO 533/483/15, 'Copy of the bill as passed in the Legislative Council the 4th November 1937: An Ordinance to amend the Native Registration Ordinance'.

${ }^{40}$ McGregor, Kenya, 189.

${ }^{41}$ KNA AG/35/17, A Victim, 'Kipandis and characters', Daily Observer, 26 Nov. 1925.
} 
those working in close proximity to white women. ${ }^{42}$ Though the registration system broadly restricted African freedom of movement, it gave greater rights of mobility to male laborers. African women, whom colonial authorities imagined as confined to the rural household, made up a relatively small portion of the formally registered (i.e. legal) migrant labor pool. ${ }^{43}$ This uneven sex ratio exacerbated concerns about the safety and respectability of white women. After a spate of crimes targeting European women and children, the colonial government introduced the Domestic Servants Registration Ordinance, which bolstered white women's control over the boundaries of the gated household. ${ }^{44}$ From 1927 onwards, any African employed as a domestic servant had to carry a pocket register (known as a red book). ${ }^{45}$ Like early versions of the kipande, the red book included a section where notes could be recorded on an African's character. Opaque to any African worker who could not read English, it was often used by European women to disparage or favor African workers. ${ }^{46}$

The use of the pocket register indicates that biometrics never swept away the 'slow and messy and unreliable paper-based systems of government'. ${ }^{47}$ As Séverine Awenengo Dalberto, Richard Banégas, and Armando Cutolo suggest, biometrics remained entangled in the

\footnotetext{
${ }^{42}$ For more on the concept of 'black peril', see C. E. Ray, 'Decrying white peril: interracial sex and the rise of anticolonial nationalism in the Gold Coast', The American Historical Review, 119:1 (2014), 78110.

${ }^{43}$ See J. L. Parpart, 'The household and the mine shaft: gender and class struggles on the Zambian Copperbelt, 1926-64', Journal of Southern African Studies, 13:1 (1986), 36-56.

${ }^{44}$ D. M. Anderson, 'Master and servant in colonial Kenya', The Journal of African History, 41:3 (2000), 459-85. See also KNA AG 35/25, 'Notes of meeting between the commissioner of police, the Office-in-Charge of Central Finger Print Bureau and the Chief Native Commissioner, held at the office of the Chief Native Commissioner on the 6th October, 1926'; KNA AG 35/25, letter from Commissioner of Kenya Police to the Chief Native Commissioner, 'Criminal records - notification to employers as to whether individuals under reference are suitable for domestic employment', 23 Nov. 1926.

${ }^{45}$ In his memoirs, Barack Obama describes being given the possessions of his late paternal grandfather. Among them was a Domestic Servant's Pocket Register. Obama, Dreams from My Father: A Story of Race and Inheritance (Edinburgh, 2007 [1995]), 425-6.

${ }^{46}$ R. Mugo Gatheru, Child of Two Worlds: Kikuyu's Story (London, 1966), 93. See also KNA AG/35/35, letter from A. I. Wise, Secretary of Sub-Committee of Labour Advisory Board, to the Chairman of the Labour Advisory Board, 7 June 1946. The East Africa Women's League sought to be included in the post-war legislative discussion surrounding registration out of a desire to protect white women and children from the purported dangers of unvetted domestic help.

${ }^{47}$ Breckenridge, Biometric State, 16.
} 
documentary state ${ }^{48}$ In fact, ID cards also generated novel modes of bureaucratic writing. This documentary assemblage was veiled, in many ways, from African discursive and communicative practices. The kipande existed within a hierarchy of documentation that linked literacy to civilizational achievement, reputational status, and racial superiority. This mirrored patterns in Britain where, as Edward Higgs notes, bodily identification (including branding and fingerprinting) had long-standing associations with criminality. ${ }^{49}$

Throughout the 1930s, literacy served as a marker of difference and a proxy for race, which enabled Kenyan officials to justify the registration system in the face of mounting criticism. By the early 1930s, the kipande had come under the scrutiny of the Labour Party and Colonial Office, which sought to avoid running afoul of the International Labour Organization (ILO).${ }^{50}$ Lord Passfield, the newly appointed Secretary of State for the Colonies and a more progressively minded Fabian, was particularly troubled by African testimony elicited during the 1931 Joint Select Committee on Closer Union in East Africa. The testimonials reported practices that seemed to contravene the tenets of the 1923 Devonshire White Paper, which had rhetorically affirmed the paramountcy of African interests. ${ }^{51}$ Appearing before the Committee, Kenyan witnesses had expressed grievances about the registration system, while those from Uganda and Tanganyika had complained about its potential introduction to their regions. Speaking on behalf of African representatives from Kenya, Chief Koinange wa Mbiyu testified that the 'registration

\footnotetext{
${ }^{48}$ S. A. Dalberto, R. Banégas, and A. Cutolo. 'Biomaîtriser les identités?' Politique Africaine, 152 (2018), 5-29.

${ }^{49}$ E. Higgs, 'Fingerprints and citizenship: the British state and the identification of pensioners in the interwar period', History Workshop Journal, 69:1 (2010), 63.

${ }_{50}$ TNA CO 533/384/9, letter from the Kikuyu Central Association to the Secretary of State for the Colonies, 14 Feb. 1929; TNA CO 533/384/9, letter from Edward Grigg to Lord Passfield, Secretary of State for the Colonies, 14 Nov. 1929. See also TNA CO 533/483/15; TNA CO 533/413/6; Parliamentary Debates, Commons, 11 Dec. 1929, 5th series, vol. 233, cols. 581-616.

${ }^{51}$ TNA CO 533/413/6, Joint Select Committee on East Africa, 'Minutes of evidence: taken before the Joint Section Committee on East Africa', 23 June 1931; and TNA CO 533/413/6, C. G. Eastwood and H. T. Allen, 'Native Registration Ordinance', 15 May 1931.
} 
certification confers no benefit of any sort to natives. ...We consider it a token of slavery'. ${ }^{52}$ Invoking slavery would have no doubt roused a Colonial Office invested in the myth-making surrounding British abolitionist history and wary of the ongoing use of forced labor in the colonies. ${ }^{53}$

Dismissing such accusations, the Governor of Kenya defended the kipande system to a concerned Colonial Office on the grounds that 'illiteracy demands special treatment' ${ }^{54}$ The 'native', he reasoned, could not read nor write and lacked a fixed address. Local naming customs, according to the Governor, also rendered African subjects inscrutable: 'The native ... commonly has a number of different names and he changes his names at different periods of life. In some cases he is even prevented by tribal custom from giving to a stranger the name by which he is known in his village' ${ }^{55}$ It was in both African and government interests, he argued, to maintain the existing registration system. Talk of cultural factors (such as non-standardized African naming and spelling conventions) became the recourse of colonial administrators.

By insisting that registration was 'based upon illiteracy rather than upon race', colonial officials were able to displace problems of racism onto a discussion of culture. ${ }^{56}$ Yet such arguments were thinly veiled. Under the Native Exemption Ordinance, English-literate Africans (upon payment of a fee) could acquire a certificate signed by the Director of Education that relieved them of the obligation to carry a kipande. However, as noted by the Governor himself, only four people in the entire colony were issued with an exemption certificate in $1931 .{ }^{57}$ Such

\footnotetext{
52 TNA CO 533/413/6, 'Evidence of native witnesses'.

${ }^{53}$ See D. R. Peterson, 'Introduction: abolitionism and political thought in Britain and East Africa', in D. R. Peterson (ed.), Abolitionism and Imperialism in Britain, Africa, and the Atlantic (Athens, OH, 2010), 1-37.

${ }_{54}^{54}$ TNA CO 533/413/6, letter from the Governor of Kenya to the Secretary of State for the Colonies, 5 Nov. 1931, 2.

${ }^{55}$ Ibid.

${ }^{56}$ TNA CO 533/413/6, letter from the Secretary of State for the Colonies to the Governor of Kenya, 10 May 1932.

${ }^{57}$ TNA CO 533/413/6, letter from the Governor of Kenya to the Secretary of State for the Colonies, 15 Sept. 1932.
} 
narrow exceptionalism belied the government's professed commitment to racial impartiality and exposed the discrepancy between metropolitan ideas of liberalism and colonial practices.

Within Kenyan historiography, the Native Registration Ordinance has largely been understood through the lens of the migrant labor system. Historians have pointed out that the kipande enabled white settlers and other employers to enforce labor contracts, track down deserters, and maintain African wages at an artificially low rate. Indeed, registration allowed the government to reduce African workers' bargaining power while instituting a tenuous balancing act between facilitating labor mobility and enforcing racial and ethnic segregation. ${ }^{58}$ Still, the kipande was experienced not only as a form of labor control but also as chain of embodied practices, what I refer to as biometric rituals, which marked blacks as inherently suspect. As the Kenyan writer R. Mugo Gatheru noted in his memoir, the registration system was grounded in 'the assumption that a large number or proportion of the Africans were inherently dishonest' ${ }^{59}$ It served to normalize, through bodily and spatial practices, the untrustworthiness of black selfpresentation and self-representation. Gatheru described a system that erased distinctions of character among Africans: 'In Kenya a policeman could stop an African on the road or in the street and demand that he produce his Kipande - regardless of whether the African concerned was as wise as Socrates, as holy as St Francis [sic], or as piratical as Sir Francis Drake'. ${ }^{60}$ The humiliation of registration was often captured in more starkly dehumanizing terms. As another Kenyan memoirist, Muga Gicaru, explained, the kipande was popularly known to Kikuyu speakers as 'mbugi, or "goat's bell”, 61

\footnotetext{
${ }^{58}$ As Zeleza explains, the kipande was 'designed to be used as an instrument with which to keep track of labour supply ... facilitate the enforcement of labour contracts' and 'standardize low wages'. T. Zeleza, 'The colonial labour system in Kenya', in W. R. Ochieng', and R. M. Maxon (eds.), An Economic History of Kenya (Nairobi, 1992), 181. See also Berman and Lonsdale, 'Crises'; and Anderson, 'Master and servant'.

${ }^{59}$ Gatheru, Child, 88.

${ }^{60}$ Ibid.

${ }^{61}$ M. Gicaru, Land of Sunshine: Scenes of Life in Kenya Before Mau Mau (London, 1958), 60.
} 


\section{REFORMISM AND BUREAUCRATIC INERTIA}

Registration created market-based reputational identities for populations with limited English literacy skills, whose legal identities had not been shaped by a history of expansive, paper-based bureaucracy.$^{62}$ For several decades, this system reinforced work contracts that tacked uneasily between free and forced labor. In fact, the kipande helped give meaning to the very concept of 'free labor' by differentiating between wage employment in white-dominated sectors and the forced and often invisible, feminized forms of work that tended to occur on reserves. ${ }^{63}$

The significance of registration, however, far exceeded market logics. By the end of the interwar period, the kipande had become an emotive symbol and performative practice that gave texture to Kenya's racialized caste system. ${ }^{64}$ Over the course of the 1930s and 1940s, substantial debate had emerged amongst members of the Colonial Office, colonial administrators, unofficial and official members of the Legislative Council (Legco), and employers and white settlers of differing ideological persuasions over the value and defensibility of registration. In spite of concerns about its mounting expense, decreasing utility, and growing political liability, the kipande survived amidst bureaucratic inertia, defensive white reactions, and the logic of reformism.

\footnotetext{
${ }^{62} \mathrm{KNA}$ DC/NYI/2/1/9, letter from Nanyuki Farmers' Association to the District Commissioner, Nyeri, 4 Mar. 1935.

${ }^{63}$ For more on the colonial use of forced labor on African reserves, see: O. Okia, Communal Labor in Colonial Kenya: The Legitimization of Coercion, 1912-1930 (New York, 2012). On the role of unfree labor in capitalist accumulation, see N. Fraser, 'Expropriation and exploitation in racialized capitalism: a reply to Michael Dawson', Critical Historical Studies, 3:1 (2016), 163-178.

${ }^{64}$ Kenyans deemed 'non-native' by colonial authorities were typically exempt from carrying the kipande. On the exemption of Somalis, see K. Weitzberg, We Do Not Have Borders: Greater Somalia and the Predicaments of Belonging in Kenya (Athens, OH, 2017).
} 
By the 1930s, the registration system had begun to break down. Already under scrutiny from the Colonial Office, the kipande's efficacy was further undermined by Depression-era budget cuts. It became easier for an increasingly literate African population to forge or discard vipande and gravitate to more popular employers. Additionally, a growing number of unregistered Africans were able to obtain work with European, Arab, and Asian employers who found it expedient to evade registration and reporting requirements. ${ }^{65}$ In 1935 , the Chief Registrar of Natives attributed the growing problem of desertion to 'the thoughtless reductions that were made in my staff in 1933' and the "'emasculation" of the Native Registration system' ${ }^{66}$ The loss of white masculine power appeared as a sublimated fear amongst defenders of the kipande system, which included several white settler farmer associations. ${ }^{67}$ In 1936 , Sir Alan Pim, a financial advisor to the Colonial Office, suggested the kipande had outlived its utility and be scrapped 'as a possible economy'. ${ }^{68}$ Yet, as Anthony Clayton and Donald Savage note, Pim 'failed to recognize that the kipande was more than a system of control. It was also a symbol of European domination as the much more spectacular debate over abolition in the nineteen-forties would show' ${ }^{69}$

The political strength of a small, but vocal white minority ensured that debates over registration gravitated towards reform rather than abolition. In 1937, the colonial government amended the Native Registration Ordinance to streamline the system and curb some of its worst

\footnotetext{
${ }^{65}$ R. Van Zwanenberg, Colonial Capitalism and Labour in Kenya, 1919-1939 (Kampala, 1975), 190; and Clayton and Savage, Government, 170.

${ }^{66} \mathrm{KNA}$ ABK/14/36, letter from the Chief Registrar of Natives to the Colonial Secretary, 6 Dec. 1935.

${ }^{67}$ See, for example: KNA ABK/14/36, letter from C. Hunter of Kenya Sisal Growers' Association to Chief Native Commissioner, 2 Dec. 1935; KNA ABK/14/36, letter from Hon. Secretary of Koru Farmers and Planters Association to the Chief Registrar of Natives, 5 Aug. 1937; and KNA ABK/14/36, letter from the Hon. Secretary of the Fort Ternan Coffee Planters' Association to the Chief Registrar of Natives, 26 Aug. 1937.

${ }^{68}$ Great Britain Commission on Financial Position and System of Taxation of Kenya and Sir Alan Pim, Report of the Commission Appointed to Enquire into and Report on the Financial Position and System of Taxation of Kenya, (London, 1936), 248.

${ }^{69}$ Clayton and Savage, Government, 170.
} 
abuses..$^{70}$ Yet this neither addressed African grievances nor allayed concerns within the metropole. ${ }^{71}$ In a 1938 editorial in The Times, Archdeacon W.E. Owen, an inveterate colonial critic, cited the cruelties of the Ordinance: 'Our pass system, represented in Kenya by the "kipandi", has consigned about 50,000 Africans to gaol or other punishment since its inception about 18 years ago. It still operates, and under it about 3,000 are convicted every year'. ${ }^{72}$

Prior to the Second World War, the robust discourse of reformism reflected a pragmatic liberalism that enabled British and colonial officials to respond to such critics while continuing to appease right-wing elements of the white settler population. Reformism was predicated on a belief in the administrative neutrality of registration whose fundamental legitimacy, in the official mind, could be retained upon 'removing certain features which may be open to objection' ${ }^{73}$ This logic, however, ran counter to the arguments of African and Indian representatives who, by the mid 1940s, were escalating demands for complete abolition of the registration system. Many leaders were also attempting to manage or co-opt more militant political forces in the country. Amidst a mounting strike wave, political actors including Jomo Kenyatta, who took over the leadership of the Kenya African Union (KAU) in 1947, publicly advocated for 'the wholesale burning of the kipande'. ${ }^{74}$ In so doing, they drew upon a long tradition of strategic civil disobedience dating back to Gandhi's anti-pass campaigns of the turn of the century and Harry Thuku's anti-kipande protests of the $1920 \mathrm{~s}^{75}$ The threat of physically

\footnotetext{
${ }^{70}$ TNA CO 533/461/12, letter from the Governor of Kenya to the Secretary of State for the Colonies, 29 Oct. 1935; TNA CO 533/483/15, 'Legal report, The Native Registration (Amendment) Bill, 1937'; and TNA CO 533/497/5, letter from the Governor's Deputy to the Secretary of State for the Colonies, 18 Sept. 1938.

${ }^{71}$ Parliamentary Debates, Lords, 9 June 1937, 5th series, vol. 105, cols. 425-66.

${ }^{72}$ W. E. Owen, 'Meaning of the Empire', The Times, 10 June 1938.

${ }^{73} \mathrm{KNA} \mathrm{AG} / 35 / 35$, 'Press communiqué: African registration'.

${ }^{74} \mathrm{KNA}$ PC/NGO/1/13/10, letter from the Secretariat to all Provincial Commissioners, 30 May 1947. See also H. Muoria, I, the Gikuyu, and the White Fury (Nairobi, 1994), 4-5, 158.

${ }^{75}$ S. Aiyar, 'Empire, race and the Indians in colonial Kenya's contested public political sphere, 1919-1923', Africa, 81:1 (2011), 132-154.
} 
destroying the kipande signaled both an act of defiance and a desire to radically rework the social and political relations that were not merely reflected, but also constituted through identification practices. ${ }^{76}$

Anti-kipande protests took on new meaning in the context of the changed and charged post-war political climate. In the wake of the Second World War, the newly elected British Labour government had begun to reimagine empire and reconfigure the racial order. In the name of developmentalism and political reform, the Kenyan administration gradually came to accept the presence of a permanent African urban class and began implementing incremental polices of Africanization. ${ }^{77}$ Rethinking registration became part and parcel of this broader transformation. In 1946, the Kenyan Labour Department established a sub-committee to assess existing registration legislation. The seven-member Committee, which included non-European leaders A. B. Patel, Eliud Mathu, and Francis Khamisi, began drafting a major overhaul of the system. ${ }^{78}$ A transformed labor market rather than political imperatives alone also made such legislative changes possible. 'Without in any way underestimating the impact of the anti-kipande protests', notes Tiyambe Zeleza, 'it has to be recognized that by this time the kipande was no longer very useful as a means of controlling labour because the problems associated with labour shortages had long since disappeared'. ${ }^{79}$

Tensions between abolitionism and reformism nevertheless colored debates over the kipande's future. Skepticism about the limits of legislative change were perhaps best captured by

\footnotetext{
${ }^{76}$ Hull, Government, 21.

${ }^{77}$ B. A. Ogot and W. R. Ochieng' (eds.), Decolonization \& Independence in Kenya, 194093 (Athens, OH 1995); B. Berman and J. Lonsdale, Unhappy Valley: Conflict in Kenya \& Africa, Volumes I and II (Athens, OH, 1992); and F. Cooper, Decolonization and African Society: The Labor Question in French and British Africa (Cambridge, 1996).

${ }^{78}$ TNA CO 533/545/1, 'Precis of the report of the sub-committee labour advisory board as adopted after amendment by the board'; and TNA CO 533/545/1, 'Recommendations of the sub-committee of the labour advisory board, as amended by the labour advisory board'.

${ }^{79}$ Zeleza, 'The colonial labour system', 181.
} 
a 1946 satirical article published in Mwalimu, an African newspaper edited by KAU Secretary Khamisi. Translated from Swahili by suspicious colonial intelligence agents, the article dismissed government efforts at reform. ${ }^{80}$ 'We are all glad to note,' the article begins with faux enthusiasm, that '[His Excellency] the Governor' will have 'his finger prints taken in order to possess the card which is given to the Africans in Kenya' ${ }^{81}$ Still as the author explained, the Governor would need to go further: 'First of all he must change his colour, he must be a blackman and never again a white man'. ${ }^{82}$ He would also have to 'walk along the River Road' (one of the main thoroughfares for African workers) and 'halt, when he is ordered by Police, in order to produce his Kipande'. ${ }^{83}$ Without facing these inequities, 'his getting of Kipande is just "Bure" (is of no account)' and 'he [the Governor] is just treating the Africans in Kenya with contempt, despising, scolding them while they are in distress' ${ }^{84}$ In other words, racial discrimination would not be effaced by a few inky white fingertips. As this piece of satire bitingly suggests, many African political thinkers saw government efforts to deracialize registration as a performative gesture that allowed larger issues of racial inequality to remain unaddressed.

Labor organizations such as the African Workers' Federation in Mombasa and the Nairobi Taxi Drivers' Union also rejected the proposed reforms, which colonial officials continued to describe, in often paternalistic terms, as a progressive and necessary administrative move. As one colonial intelligence agent dismissively remarked: 'I think we ought to endeavor to explain to these stupid people that taxi-cab drivers in London and New York' also have 'to

\footnotetext{
${ }^{80} \mathrm{KNA} \mathrm{AG} / 35 / 36$, letter from the Ag. Member for Law and Order to the Acting Chief Secretary, 8 July 1947.

${ }^{81} \mathrm{KNA} \mathrm{AG} / 35 / 35$, confidential letter from the Director of Intelligence and Security to the Member for Law and Order, 11 Dec. 1946.

${ }^{82} \mathrm{Ibid}$.

${ }^{83} \mathrm{Ibid}$.

${ }^{84}$ Ibid.
} 
wear a large badge' and 'exhibit their licenses'. ${ }^{85}$ Committed to the idea of identification as a neutral and universal feature of modern life, he refused to entertain the complaints of a more radicalized and politicized sector of workers for whom registration was yoked to a charged, racialized past.

In 1947, after ample debate in the Legislative Council, the Native Registration Ordinance was amended and repealed and the Registration of Persons Ordinance introduced. ${ }^{86}$ These legislative changes introduced universal fingerprint registration for all men in the Colony, separated identity cards from employment records, barred the police from arbitrarily arresting Africans who could not produce identification, and removed the obligation that Africans carry a certificate of registration on them at all times. ${ }^{87}$ Mathu, until 1946 the sole African representative in the Kenya Legislative Council, conceded to these reforms, which promised to deracialize identity documents, lessen police abuses, and improve the labor conditions for African workers. As a gesture towards racial equity, the colonial government promised to begin the registration drive with the European and Asian populations. ${ }^{88}$ In the interim, Africans could apply to a registration officer to have their kipande cut in half — thus divorcing their proof of identity on the upper portion of the certificate from their employment record on the lower half. ${ }^{89}$ Women,

\footnotetext{
${ }^{85} \mathrm{KNA} \mathrm{AG} / 35 / 36$, letter from Ag. Member for Law and Order to the Acting Chief Secretary, 8 July 1947.

${ }^{86} \mathrm{KNA}$ AG 35/35, Labour Commissioner, 'Memorandum on amendments required to the Native Registration Ordinance, Chap. 127 Laws of Kenya to implement recommendation of the report of the sub-committee of the Labour Advisory Board'; TNA CO 533/545/2, Colony and Protectorate of Kenya, 'An ordinance to amend the Native Registration Ordinance', no. XXXII of 1947; and TNA CO 533/545/2, Colony and Protectorate of Kenya, 'An ordinance to make provision for the registration of persons in the colony for the issue of identity cards and for purposes connected therewith', no. XXXIII of 1947.

${ }^{87}$ TNA CO 533/545/2, 'Legal report: the Native Registration (Amendment) Ordinance, 1947'; TNA CO 533/545/2, 'Legal report: the Domestic Employment (Certificate of Registration) Ordinance, 1947'; TNA CO 533/545/2, Colony and Protectorate of Kenya, Ordinance No. XXXIII of 194n Ordinance to Make Provision for the Registration of Persons in the Colony, for the Issue of Identity Cards and for Purposes Connected Therewith, 1947. ${ }^{88}$ TNA CO 533/545/3, Hon. E. W. Mathu, 'The Kipande Controversy', 29 Apr. 1949.

89 TNA CO 533/562/1, Colony and Protectorate of Kenya, 'Report of a Commission of Inquiry Appointed to Review the Registration of Persons Ordinance', 1947, 1950, 6-9.
} 
whose legal identities were still mediated through husbands and fathers, were largely excluded from this discussion.

Although the 1947 Registration of Persons Ordinance marked a significant victory for African leaders, it fell short of African demands and also furthered the normalization of a technology intimately linked to the history of British imperial expansion and capitalist domination. ${ }^{90}$ Moreover, this reformist drive produced its own logic, enabling reactionary white settlers to frame their opposition to fingerprinting within a critique of authoritarianism and through the same liberal terms long used by colonial authorities to defend the kipande.

\section{WHITE BACKLASH}

The Registration of Persons Ordinance was passed with little fanfare in 1947 despite some objections from the Indian government and representatives of the Indian communities in Kenya. ${ }^{91}$ Yet only two years later, when the colonial government sought to implement the terms of the Ordinance, a vocal group of white settlers began to mobilize against the legislation. Fingerprinting became a metonym for a wider set of post-war anxieties — the threat of authoritarianism, the rise of socialism, the emergence of new powers on the world stage, and the growing demands of educated African nationalists — all of which seemed to spell the loss of British prestige and white power. ${ }^{92}$

\footnotetext{
${ }^{90}$ Ogot and Ochieng', Decolonization; Berman and Lonsdale, Unhappy Valley; Cooper, Decolonization.

${ }^{91}$ TNA CO 533/545/1, telegram from the Government of India External Affairs and Commonwealth Relations Department to the Secretary of State for Commonwealth Relations, 21 Sept. 1947; and TNA CO 533/545/1, 'Extract from record of meeting between the Secretary of State and Mr. Krishna Menon', 1947; and TNA CO 533/545/1, A. R. Cocker, 'Minority report'.

${ }^{92}$ TNA CO 533/545/3, The Society for Civil Liberties, 'Fingerprints! preliminary analysis exposing the Labour Department's proffered case for national registration', 1949.
} 
The discourses circulating among the more intransigent factions of the white settler community were given expression by R. R. Stokes, a Labour Member of Parliament in the UK. In 1949, he wrote to the Colonial Office on behalf of a former constituent living in Kenya:

A correspondent who used to live in my constituency has written complaining of the regulation which insists on fingerprints being taken of everyone in Kenya. As she points out the settlers are not 'white savages' and most of them have fought or served in the two European wars. They bitterly resent a measure that levels the literate down to the illiterate. It is explained that all the literates, Africans, Arabs, Europeans and Indians are opposed to it and the opposition has nothing whatever to do with any racial feeling. ${ }^{93}$

Etienne Balibar argues that oblique cultural racism is a product of the post-Cold War era.

Yet, as this letter attests, culture talk has long been a feature of colonial discourse. ${ }^{94}$ The language of liberal reformism was easily appropriated by more resolutely racist and intransigent settlers, who used literacy as an excuse to reject universal fingerprinting.

Framed as a matter of universal civil liberties, imperial loyalty, and British prestige, the complaints of a tiny, yet powerful, minority gained reception among metropolitan authorities and Members of Parliament. The letters entreating metropolitan officials to intervene on settlers' behalf portrayed universal registration as an appeasement of radical forces amongst the African population. In December 1951, a Kenyan settler wrote to the Colonial Secretary to protest that fingerprinting was an affront to her husband, a decorated soldier who had fought in both world wars: 'It is iniquitous that men like my husband ... should be reduced to the level of illiterate Africans and be forced under threat of prosecution, to give their thumb and finger prints on an

\footnotetext{
${ }^{93}$ TNA CO 533/543/3, letter from R. R. Stokes to Arthur Creech Jones, 23 May 1949.

${ }^{94}$ E. Balibar, 'Is there a 'neo-racism'?' in E. Balibar and I. M. Wallerstein (eds.), Race, Nation, Class: Ambiguous Identities (London, 1991), 17-36. According to Ann Laura Stoler, "these features of the "new" racism are familiar colonial conventions firmly rooted in earlier discourses that linked race, culture, and national identity, discourses elaborated in Europe's "laboratories of modernity" - the colonies'. Stoler, Carnal Knowledge and Imperial Power: Race and the Intimate in Colonial Rule (Berkeley, 2002), 97.
} 
Identity Card — for no earthly reason than to appease a handful of semi-educated but politically minded Africans'. ${ }^{95}$

The problem of white backlash — today associated with the election of Donald Trump and the rise of right-wing populism in Europe — is hardly new. ${ }^{96}$ A perceived affront to white privilege, fingerprinting became a rallying cry for many colonists anxious about the changing post-war order. In April 1949, Mathu wrote that 'the African is now astounded to see that the white unofficial community is agitating almost to the degree of irrationality against the system they accepted both in 1946 and 1947 $\cdot{ }^{97}$ Events in South Africa, which continued to serve as an aspirational model for Kenyan settlers, likely helped precipitate the controversy. In 1948, the apartheid government came to power and, two years later, passed legislation dictating that every South African inhabitant be registered according to their race. ${ }^{98}$ South Africa's temporal trajectory seemed to run counter to that of Kenya, where the tenor and militancy of African national movements was also gaining pace. Opponents of fingerprinting expressed concern about 'constitutional changes ... pending in the Colony', which they feared would 'weaken' their position and 'increase the legislative power of other races' ${ }^{99}$ Suspicion of, if not open hostility to, the Labour Party also informed settler responses. As Michael Blundell explained, the registration issue incited recent arrivals 'who had left England because they could not adjust themselves to the changes and the social revolution of $1945^{\prime} .100$

\footnotetext{
${ }^{95}$ KNA ABK 14/221, letter from May Dann to the Colonial Secretary, 4 Dec. 1951.

${ }^{96}$ V. R. Newkirk II, 'Five decades of white backlash', The Atlantic, 15 Jan. 2018, https://www.theatlantic.com/politics/archive/2018/01/trump-massive-resistance-history-mlk/550544/.

97 TNA CO 533/545/3, Hon. E. W. Mathu, 'The kipande controversy', 29 Apr. 1949, 3.

${ }^{98}$ D. Posel, 'Race as common sense: racial classification in twentieth-century South Africa', African Studies Review, 44:2 (2001), 87-114.

${ }^{99}$ KNA ABK 14/223, The Society for Civil Liberties, 'Exodus?', 1.

${ }^{100}$ Sir M. Blundell, So Rough a Wind: The Kenya Memoirs of Sir Michael Blundell (London, 1964), 81.
} 
A member of the Kenya Legislative Council and among the more liberal white settlers, Blundell saw fingerprinting in a paternalistic vein — as an irksome, but necessary imposition that served a tutorial function for Africans: 'To myself and my supporters there seemed no fundamental objection to fingerprinting as such ... just as I had been swabbed years earlier with iodine and stuck with a needle to induce them [the Africans] to accept inoculation for plague'. ${ }^{101}$ Fingerprinting, as described by Blundell, was part and parcel of a narrative of technological progress tied to post-war developmentalist dreams. Though animated by common logics, the settler community was divided between those who saw themselves as the vanguard of a multiracial society and those who sought to further entrench segregation. ${ }^{102}$ These competing visions speak not only to the internal diversity of the settler community but also to differing ways of constructing whiteness. Though sympathetic and ultimately supportive of an alternative form of identification, Blundell cast himself as a progressive settler charting a path towards racial reconciliation and blamed the controversy for 'set[ting] alight the beginning of a reactionary and strongly racialist movement' ${ }^{103}$

Under pressure to allay the growing controversy, the colonial government conceded to a commission of inquiry headed by Sir Bernard Glancy, former Governor of the Punjab, to review the new registration system. ${ }^{104}$ The Glancy Report recommended an alternative, photographic method of registration for literate populations (which it narrowly defined as those knowledgeable

\footnotetext{
${ }^{101}$ Ibid. 80. Interestingly, Gandhi also drew comparisons between vaccines and fingerprinting. For more on Gandhi's fraught relationship with fingerprinting, see K. Breckenridge, 'Gandhi's progressive disillusionment: thumbs, fingers, and the rejection of scientific modernism in Hind Swaraj', Public Culture, 23:2 (2011), 331-348. 102 Lonsdale, 'Kenya'.

${ }^{103}$ Colony and Protectorate of Kenya, Legislative Council Debates: Official Report, Volume XLI, 3rd session, 2nd sitting (13 Feb.-9 Mar. 1951), cols. 517-20; and Blundell, So Rough, 81.

104 TNA CO 533/545/3, 'Commission will investigate', East African Standard, 17 Aug. 1949; TNA CO 533/545/3, telegram from Sir P. Mitchell, Governor of Kenya, to the Secretary of State for the Colonies, 18 Oct. 1949; TNA CO 533/545/3, letter from Sir Waldron Smithers to Arthur Creech Jones, 3 Oct. 1949.
} 
of English). It also advocated a voluntary record of employment for African workers. ${ }^{105}$ These findings emboldened the Society for Civil Liberties, a right-wing white settler advocacy group founded to oppose the Registration of Persons Ordinance. Riddled with internal contradictions, their publications teetered between an explicitly racialized language and a more palatable discourse of civil rights, while dramatizing an anti-authoritarian stance. In one pamphlet, Exodus?, the Society framed their struggle in biblical terms, drawing comparisons between the Kenyan Governor and the wicked Pharaoh. Exodus? lamented the decline of white power while insisting that opposition to fingerprinting was non-racialist in nature:

If the White Settlers do not stand together during the coming year, it may be that in five or ten years white settlement itself will be only a memory in a black colony. ... The Society, while insisting upon the adoption of that portion of the Glancy Report which deals with exemption from fingerprinting, does not do so on any ground of racial prejudice, but desires exemption for literate and responsible men OF ALL RACES. The Society believes in equality before the law IRRESPECTIVE OF RACE. ${ }^{106}$

A fever dream of post-war anxieties featured in the hyperbolic complaints of white settlers. ${ }^{107}$ Settlers drew menacing analogies between the British Empire, Nazi Germany, and authoritarian regimes in Latin America and the Soviet Union. As Richard Frost recorded, '[o]ne postwar immigrant wrote to The East African Standard prophesying that Europeans would be hauled off to police stations and subjected to treatment made infamous in Europe by the Nazi Gestapo'. ${ }^{108}$ Another complainant wrote directly to Winston Churchill: 'You, who steered our Nation to victory against the forces of evil, cannot possibly agree that loyal Britons should be

105 TNA CO 533/562/1, Colony and Protectorate of Kenya, 'Report of a Commission of Inquiry Appointed to Review the Registration of Persons Ordinance, 1947', 1950. Photography was not considered as a method of universal registration due to both its expense and purported inefficacy compared to fingerprints.

${ }^{106}$ KNA ABK 14/223, The Society for Civil Liberties, 'Exodus?', 3-4. Emphasis in original.

${ }^{107}$ KNA ABK 14/221, 'Petition to Queen against fingerprinting', East African Standard, 13 May 1952; and KNA ABK 14/221, W. T. Shapley, Society for Civil Liberties, 'Memorandum annexed to the petition to her majesty the Queen relating to the Registration of Persons Ordinance, Kenya, 1947.'

${ }^{108}$ R. Frost, The Enigmatic Proconsul: Sir Philip Mitchell and the Twilight of Empire (London, 1992), 202. 
treated the same way as convicted criminals - and the Inhabitants of Venezuela. Even the poor tortured population of Soviet Russia and her oppressed satelites [sic] is spared this degradation'. ${ }^{109}$ Painting fingerprinting as anathema to the British character, the author conflated the waning of white power with the loss of democratic freedom. ${ }^{110}$ Yet for all their anxiety about encroaching 'authoritarianism', white settlers in Kenya were free to come to meetings fully armed and speak out in full opposition to the registration policy. Blundell described a mass meeting in his constituency: 'One of my fiery opponents strode up and down the gangway of the hall with two large pistols hanging from his belt and flapping against his thighs during the voting'. ${ }^{111}$ Such menacing expressions of armed autonomy speak to the persistence of white male hegemony in the Colony.

However exaggerated, settler concerns seem to have found resonance in the metropole, where a parallel public debate was taking place over the compulsory IDs introduced at the start of the Second World War. In 1950, the Liberal activist Harry Willcock was arrested in London for refusing to produce his ID to a police constable. His trial and the controversy it engendered eventually led to the repeal of the 1939 UK National Registration Act. Willcock's case reaffirmed the links between the suspension of civil liberties and compulsory IDs. Within the wider British imaginary, mandatory IDs remained an exceptional measure intended for colonized subjects, criminals, or as a temporary wartime measure. ${ }^{112}$

\footnotetext{
109 TNA ABK 14/221, letter from H. Groombridge to Winston S. Churchill, 24 Nov. 1951.

${ }^{110}$ See also KNA ABK/14/221, letter from Harold Groombridge to the Secretary of State for the Colonies, 20 Nov. 1951; TNA CO 533/545/3, The Society for Civil Liberties, 'Fingerprints!'; KNA ABK/14/221, 'The petition of certain British subjects of the Colony' to Sir Philip Mitchell, Governor of Kenya.

${ }^{111}$ Blundell, So Rough, 80.

112 J. Agar, 'Modern horrors: British identity and identity cards', in Caplan and Torpey (eds.), Documenting Individual Identity, 101-20; and KNA ABK 14/221, W. T. Shapley, Society for Civil Liberties, 'Memorandum annexed to the petition to her majesty the Queen relating to the Registration of Persons Ordinance, Kenya, 1947.
} 
Though Kenyan colonial authorities did not fully concede to settler demands, they enabled them to reshape the registration initiative. The Governor chose not to implement key findings of the Glancy Report despite its adoption by a majority vote in the Kenya Legislative Council. ${ }^{113}$ This was done out of concern that appeasing white interests would precipitate a 'mass burning of registration certificates' by African protestors, encourage political alliances between Africans and Indians, and provide fodder for Communist agitation and infiltration. ${ }^{114}$ Nevertheless, the government's claim to be a neutral arbiter opposed to racial discrimination was undermined by the actual practice of registration. Registration officers allowed settlers, who faced few consequences for opting out, to come forward on a voluntary basis. ${ }^{115}$ Nor was the new identity card shorn of its racialized antecedents. Registration was not only done on a racial basis, but Kenyan residents continued to be indexed within the state's vast filing cabinets according to racial category. ${ }^{116}$

An enduring personal archive, the kipande also did not fade out of use immediately. By the post-war period, the registration certificate had developed into a coveted item among workers who had a need or aspirational desire to participate in the formal economy. Many colonial officials and African workers recognized that a work record (even if technically voluntary) remained a de facto prerequisite for many kinds of employment. Some men resisted the cutting

\footnotetext{
113 TNA CO 533/562/2, Secretariat, Nairobi, ‘The Glancy Report', Dec. 1950; and TNA CO 533/562/2, 'A national register', The East African Standard, 16 Jan. 1951. The single European Elected Member who voted against the adoption of the Glancy Report, Derek Erskine, subsequently resigned from his seat in the Council. J. R. Roelker, Mathu of Kenya: A Political Study (Stanford, CA, 1976), 93.

114 TNA CO 533/562/1, note from Mr. Campbell to Mr. Newsam, 23 Nov. 1950; and Brückenhaus, 'Identifying colonial subjects', 82 .

${ }^{115}$ Clayton and Savage, Government, 296; Frost, Enigmatic Proconsul, 205; and KNA ABK/14/221, letter from Governor of Kenya to Oliver Lyttelton, Secretary of State for the Colonies, 25 June 1952.

${ }^{116}$ KNA ABK/14/219, Colony and Protectorate of Kenya, 'Registration of Persons National Registration: What Do They Mean?' (Nairobi), 45-58.
} 
of their vipande out of fear of invalidating hard-won records of service. ${ }^{117}$ European members of the Legislative Council seized upon African reluctance to having the kipande cut to extol the merits of its work record. In this way, disempowerment was translated into consent. ${ }^{118}$ In March 1951, the Legislative Council passed amended legislation which stipulated that Africans could have their vipande retained and endorsed as a record of service and introduced a new voluntary work record (known as the 'buff card'). ${ }^{119}$ Nominated African members such as James Jeremiah objected on the grounds that the Legislative Council was in effect 'reintroducing the kipande in a new form'. ${ }^{120}$ Between exclusion and participation in the formal marketplace lay the interface of registration. In this way, Kenya's economy remained predicated upon a form of reputational identity that rendered Africans suspect and privileged literate European and Indian owners of capital.

Despite the gradual introduction of a new identification certificate, cut and uncut vipande remained in currency, providing a sedimentary layer upon which the new system developed. The old registration system also lived on in other ways. In 1952, only a year after the fingerprinting controversy had died down, Kenya's Governor declared a state of emergency to quell a nascent anti-colonial rebellion and internal civil war popularly known as 'Mau Mau'. To suppress the insurgency, the colonial government introduced passbooks for the entire Kikuyu, Embu, and

117 TNA CO 533/562/2, Press office handout no. 20, 'Registration of Persons Ordinance'; TNA CO 533/562/2, Secretariat, Nairobi, 'The Glancy Report', 30 Dec. 1950; TNA CO 533/562/1, Colony and Protectorate of Kenya, 'Report of a Commission of Inquiry Appointed to Review the Registration of Persons Ordinance, 1947', 1950, 7-8. ${ }^{118}$ Colony and Protectorate of Kenya, Legislative Council Debates: Official Report, Volume XLI, 3rd session, 2nd sitting (13 Feb. 1951-9 Mar. 1951), cols. 447-51.

${ }^{119}$ Official Gazette of the Colony and Protectorate of Kenya, Vol. LIII, no. 5, 'A bill entitled an Ordinance to Amend the Registration of Persons Ordinance', 16 Jan. 1951, 53-6; Colony and Protectorate of Kenya, Legislative Council Debates: Official Report, Volume XLI, 3rd session, 2nd sitting, (13 Feb. 1951-9 Mar. 1951), cols. 447-542.

${ }^{120}$ Legislative Council Debates: Official Report, Volume XLI, 3rd session, 2nd sitting, (13 Feb. 1951-9 Mar. 1951), col. 527. The trade unionist Makhan Singh wrote that the "new system of identity cards and work cards ("Buff Cards")' had 'the same purpose as was served by the old kipande, with the difference that there were a few modifications in the penal sanctions and that the new system was on a non-racial basis'. Singh, History of Kenya's Trade Union Movement to 1952 (Nairobi, 1969), 154. 
Meru populations of Central Kenya, which greatly restricted their freedom of movement. African civil liberties were thus swept aside amidst the hysteria surrounding Mau Mau. In this way, an identity document akin to the kipande was reintroduced in the name of securitization. ${ }^{121}$

\section{CONCLUSION: DERACIALIZING BIOMETRICS?}

The history of the kipande highlights both the centrality of Kenya to the making of global registration systems and the need to re-center Africa within the history of racial capitalism and modern governance. ${ }^{122}$ An elastic technology that traveled between metropole and colony, fingerprinting has long been a locus of debate over workers' rights, the reach of government power, the relationship between race and citizenship status, and the extraterritorial position of imperial subjects and foreigners. Similarly, modern regimes have used identity cards both to confer rights and to demarcate people, spaces, and times that warrant the (often-permanent) deferral of civil liberties, thus delineating the state of exception (the suspension of normal legal liberties). ${ }^{123}$ Within Britain and its empire, fingerprinting and compulsory IDs have been applied to those without full citizenship rights (such as colonial laborers and criminals), spaces of heightened security (like the border), and exceptional times (including periods of war and emergency).

The kipande also reveals how racial capitalism was enacted and routinized through mundane, daily techniques of registration and identification, whose effects have not been wellexplored. As the controversy over universal registration in Kenya shows, racial subjectivities

\footnotetext{
${ }^{121}$ M. Likimani, Passbook Number F.47927: Women \& Mau Mau in Kenya (London, 1985). See also KNA ABK/11/1.

122 J. Comaroff and J. L. Comaroff, 'Writing theory from the South: the global order from an African perspective', World Financial Review (Sept.-Oct. 2013), 17-20.

${ }^{123}$ G. Agamben, State of Exception, trans. K. Attell (Chicago, 2005).
} 
were made not only through market relations, but also via embodied bureaucratic and documentary practices. Even as the kipande system began to outlast its explicit economic function, it continued to serve as a metonym for white dominance. Settlers and officials had become invested in the bureaucratic infrastructures and archives that reinforced the boundaries of whiteness and market-based reputational status.

Examining the enduring materiality of the kipande over the first half of the twentieth century serves as an important chapter in the prehistory of twenty-first-century digital biometrics. Today, across the postcolonial world, governments and non-governmental organizations are using fingerprint and iris scans for a range of activities — from national elections to refugee registration to aid distribution. To many proponents, biometrics are a tool for promoting greater democratic participation and financial inclusion. Even scholars who are less than sanguine about such technologies have argued that biometrics have the potential to serve progressive functions. Breckenridge describes fingerprinting in contemporary South Africa as a post-racial technique capable of 'improving the prosperity of those at the bottom of the social order' ${ }^{124}$

So often effaced, however, within contemporary narratives of technological disruption (and the much-heralded idea of 'leapfrogging') is the long, troubled history of what is essentially a nineteenth-century British imperial invention. ${ }^{125}$ If digital biometrics are to become integral to new forms of social and economic redistribution (as some sociologists and anthropologists have

\footnotetext{
${ }^{124}$ Keith Breckenridge maintains that 'in almost every respect the new biometric systems are the political antithesis of Galton's eugenicism' and 'offer intensely individualised identification in place of race and caste'. Breckenridge, Biometric State, 166. For scholarship on the in-built racism within technologies, see S. Magnet, When Biometrics Fail: Gender, Race, and the Technology of Identity (Durham, 2011); S. U. Noble, Algorithms of Oppression: How Search Engines Reinforce Racism (New York, 2018); and Ruha Benjamin, Race After Technology: Abolitionist Tools for the New Jim Code (Cambridge, MA, 2019).

${ }^{125}$ According to recent iterations of modernization theory, 'developing' countries can bypass earlier phases of technology and leapfrog to more advanced stages of development. An oft-cited example is the mobile phone, which has become commonplace in non-industrialized countries that lack an extensive landline infrastructure.
} 
suggested), then it is imperative to consider the racialized pasts and afterlives of these technologies. ${ }^{126}$ Today, digital biometric technologies — though no longer as explicitly racialized — are applied in a highly uneven fashion across the globe. They are far more ubiquitous in postcolonial countries, where they are governed by significantly less scrutiny, transparency, and consent than is the norm in the Global North. Rather than extracting labor, new biometric registration schemes are creating inroads for expropriating wealth from African populations. ${ }^{127}$ Such innovations have particularly fraught implications in countries like Kenya, where the biometric surveillance of refugees has become normalized and where national IDs are no longer used to police the boundaries between 'native' and settler, but between 'indigenous' and 'foreigner'. ${ }^{128}$

The controversy in late colonial Kenya suggests that biometrics may be a malleable technology, but it is yoked to a charged history and tied to bureaucratic infrastructures, archives, and embodied practices often slow to change. For all its promises of emancipatory, disruptive change, digital technologies are layered atop analog pasts. ${ }^{129}$ The paper trails, material traces, and bureaucratic echoes of Kenya's racialized registration system have given the kipande an

\footnotetext{
${ }^{126}$ James Ferguson, for example, argues that 'the development of more effective and inclusive techniques for identifying biological individuality should not be thought of as automatically regressive or politically objectionable'. He goes on to argue that 'new technical forms of identity documentation and recognition ... could in fact facilitate more effective and inclusive forms of state support and recognition even while requiring less, rather than more, intrusive surveillance'. Ferguson, Give a Man a Fish: Reflections on the New Politics of Distribution (Durham, 2015), 86.

${ }^{127}$ Breckenridge has coined the term 'biometric capitalism' to describe the capturing of the 'informal' economy through new biometric and financial technology. K. Breckenridge, 'Biometric capitalism: infrastructures of identification and credit risk on the African continent in the 21st Century', (paper presented at Technosphere $\mathrm{x}$ Knowledge, Haus der Kulturen der Welt, Berlin, 15 Apr. 2016).

${ }^{128}$ See K. B. Sandvik and K. L. Jacobsen (eds.), UNHCR and the Struggle for Accountability: Technology, Law and Results-Based Management (London, 2016); and S. Balaton-Chrimes, 'Statelessness, identity cards and citizenship as status in the case of the Nubians of Kenya', Citizenship Studies, 18:1 (2014), 15-28.

${ }^{129}$ N. Nyabola, Digital Democracy, Analogue Politics: How the Internet Era is Transforming Politics in Kenya (London, 2018).
} 
enduring afterlife as well as a currency within popular memory. As Gatheru so succinctly writes, even after it was abolished, 'the scars of Kipande remained'. ${ }^{130}$

${ }^{130}$ Gatheru, Child, 89. 